Ankara Üniversitesi Türk İnklâp Tarihi Enstitüsü Atatürk Yolu Dergisi S 37-38, Mayı-Kasim 2005, s. 231-245

\title{
Kore Savaşı'nın Türk Kamuoyuna Yansıması
}

\author{
Ahmet Emin YAMAN \\ ÖZET
}

II. Dünya Savaşı sonrası oluşan çift kutuplu dünyada şiddetini artıran soğuk savaş Kore'de silahlı çatışmaya dönüştü. Türkiye, benzer bir saldırıya uğrayabileceği varsayımı ve dünya barışının geleceği endişesi ile TBMM'nin onayını almaksızın Kore'ye asker gönderdi. Güvenliği için Avrupa ile bütünleşmek, NATO'ya üye olmak ana hedef olarak belirlendi. Kamuoyu da bu paralelde yönlendirildi, desteği alındı. Kore'de Türk askeri birliğinin varlı̆̆l ve 1945 yılından beri süregelen Sovyet tehdidi algılaması, kamuoyu duyarlılığını sürekli kıldı.

Anahtar Kelimeler: Türk Kатиоуи, Kore, ABD, SSCB, Çin, Birleşmiş Milletler Ordusu, NATO, Basin, Tehdit.

\section{ABSTRACT}

Cold war which has increased its violence over the bipolar World that became into existence following the Second World War, turned into an armed conflicht in Korea. Turkey, on the assumption that she will be faced with a similar aggression and also feeling a concern towards the future of global peace, sent her troops to Korea without obtaining the approval of Turkish National Grand Assembly. Its main target was set as to provide the integration with the Europe and become a member of NATO for her security. The public opinion was also driven in this direction and its support was obtained. The existence of Turkish military troops in Korea and her sensing of Soviet threats which have been posed since 1945, maintained the sensitivity that felt by the public opinion in this regard.

Keywords: Turkish Public Opinion, Korea, USA, Soviet Socialist Republics Union, China, Army of United Nations, NATO, Pres Media, Threat. 
II. Dünya Savaşı dünya siyasi dengelerini değiştirdi. Yeni dünya düzeninde, $\mathrm{ABD}$ ve Sovyetler Birliği kıyasıya rekabet eden iki süper güç olarak ortaya çıtı. Kore sorunu', Kahire, Yalta, Postdam konferanslarında ele alındı. Japonların Kore'den çıkarılması görevi ABD ve Sovyet ordularına verildi. ABD'nin teklifi ile 38. paralelin kuzeyi Sovyetler, güneyi $\mathrm{ABD}$ tarafından Ağustos ve Eylül 1945'de işgal edildi. ABD, İngiltere, Sovyetler Birliği ve Çin tarafından Kore'de demokratik bir yönetim kurulması için Aralık $1945^{\prime}$ de oluşturulması kararlaştırılan Karma Komisyonun anlaşamaması üzerine sorun çıkmaza girdi.

$\mathrm{ABD}$, sorunu BM'ye taşıdı. Sovyetler Birliği'nin muhalefetine rağmen kabul edilen 14 Kasım 1947 tarihli karara göre oluşan BM Geçici Kore Komisyonu; Kore'de çalışacak, istişarelerde bulunacak ve 31 Mart 1948'de seçim yapılmasını sağlayacaktı. Kurulacak Kore Hükümeti, milli kuvvetler oluşturacak, buna dahil olmayan askeri teşkilatları kaldıracak, işgal kuvvetlerinin 90 gün içinde çekilmesi için gerekli önlemleri alacaktı ${ }^{2}$. Sovyetler Birliği komisyonun kuzeye girmesine izin vermedi. Bütün ülkede yapılamayacağı anlaşılan seçimler, Mayıs 1948'de sadece Güney Kore'de yapıldı. Temmuz'da Kore Cumhuriyeti ilan edildi. K. Kore'de Mayıs 1945 'de yönetimi ele alan Halk Şurası, Temmuz 1948 tarihinde seçim yaptı. Eylül'de Kore Halk Cumhuriyeti'ni kurdu. İki hükümet de kendilerini Kore'nin tek temsilcisi ilan etti. ABD ve Sovyetler Birliği işgale son vermekle birlikte, yandaş hükümetlerle ikili anlaşmalar yaparak bölgedeki nüfuzlarını korudular ${ }^{3}$.

Kore sorunu, K.Kore kuvvetlerinin 25 Haziran 1950 günü G.Kore sınırını oluşturan 38. paralel boyunca saldırıya geçmesiyle savaşa dönüştü. K.Kore ültimatomunda; Kore'nin birleşmesi, yabancı askeri ve siyasi komisyonların ülkeden çıkarılmaları yer alıyordu. ABD'nin isteğiyle toplanan BM Güvenlik Konseyi, K.Kore'nin barışı bozduğuna karar vererek; "Silahlı taarruzu geri püskürtmek ve barışı iade etmek için" Kore Cumhuriyeti'ne yardım yapılmasını istedi ${ }^{4}$.

Savaşın üçüncü gününde Seul ve daha sonra Suvon, Pyenytek ve Chanon K.Kore'nin eline geçti. Amerikan kuvvetlerinin savaşa girmesiyle paniği üzerinden atan BM Ordusu, 10 Temmuz'dan itibaren saldırıları

'Kore, Asya'nın doğusunda 34-43 paralel ve 124-130 meridyenleri arasında, Cin ve Sovyetler Birliği ile karadan, Japonya ile denizden komşu yarımadadır. Tarihte, stratejik üs olarak görülen Kore'ye 1910 'da Japonya yerleşmiş, egemenliğini 1945 yılına kadar devam ettirmisti. Hüsnü Emir Erkilet, T. Bıyıkoğlu, H. Arun, Kore Harbinde Türk Silahlı Kuvvetlerinin Muharebeleri (1950-1953), Ankara, 1975, s.13-18; Gazi Doğan, "Kamuoyunda Kore Savaşı", Y.Lisans Tezi, Ankara, 2004, s.8-12; Tahsin Yazıcı, Kore Hatıralarım, Ülkü Basımevi, Istanbul, 1963, s.7.

${ }^{2}$ Erkilet, a.g.e., s.19-21

3a.g.e., s.25-30. Amerika, askeri danıșmanlardan oluşan 500 kișilik uzmanlar grubu dışında Güney Kore'yi, 29 Haziran 1949'a kadar boşalttı. Sovyetler, 1948 yılı Aralık ayında Kore'yi boşaltacağını bildirdi. Ancak, boşaltmanın kontrol edilmesine izin vermedi.

${ }^{4}$ Hürriyet, "Kore'de Harp Basladı", 26 Haziran 1950; Milliyet, "Kore'de Dün Fiilen Harp Başladı", 26 Haziran 1950; Hürriyet, "Birleşmiş Milletler Fiilen Müdahalede Bulunacak", 29 Haziran 1950. 
durdurmayı başardı ${ }^{5}$. K.Kore, Temmuz 1950 sonlarından Eylül ortalarına kadar yaptığı saldırılarla sınırlı başarılar kazandı ${ }^{6}$.

BM Ordusu, 15 Eylül 1950 de Seul yakınlarındaki Inchon'a çıkarma yaptı. 28 Eylül'de Seul geri alındı ${ }^{7}$. K.Kore Ordusu büyük kayıplar vererek geri çekilmek zorunda kaldı. 8 Ekim'de, 38. paralel aşılarak Başkent Pyongyang ele geçirildi ${ }^{8}$. Çin, Pyongyang'ın düşmesi üzerine komşusunun işgaline kayıtsız kalamayacağını ilan etti. Kore'nin kendisi için birinci derecede önemli olduğunu vurgulayarak; Amerika'yı, Kore vasıtasıyla Çin ve Asya'yı işgal etmeye kalkıșmakla suçladı̀ .

BM Ordusunun 24 Kasım 1950'deki genel saldırısı üzerine, Çin'in "gönüllüler" den oluşan ordularını 26 Kasım'da karşı saldırıya geçirmesi paniğe neden oldu ${ }^{10}$. Çin kuvvetlerinin kuşatma harekatını önleme görevi aynı gün bölgeye ulaşan Türk Tugayı'na verildi. BM Ordusu, 30 Kasım'dan itibaren önce Pyongyong sonra da Seul'e geriledi" ${ }^{11}$. 31 Aralık'taki büyük saldırı, BM Ordusunun durumunu sarstı. Seul boşaltıldı ${ }^{12}$.

Çin hücumu devam ederken, BM'nin Kore anlaşmazlığını çözme girişimleri Sovyetler ve Çin tarafından yetersiz bulundu ${ }^{13}$. Amerikanın diplomatik çabaları sonucu BM, Çin'i saldırgan ilan etti. Başta Hindistan olmak üzere bazı devletler, üçüncü dünya savaşına meydan vermemek düşüncesiyle karara sıcak bakmadılar ${ }^{14}$. Anlaşmazlığı çözme girişimleri sonuçsuz kalırken, K.Kore 1951 yılının ilk yarısında yaptı̆̆ 1 hücumlarla savaşı zaferle sonuçlandırmaya çalıştı. Mayıs 1951'deki büyük hücumu durdurulduktan ve BM Ordusu 38. paralel üstüne yerleştikten sonra çarpışmalar mevzi savaşına dönüştü. İki taraf için de barış yapmaktan başka

${ }^{5}$ Hürriyet, "Komünistler Seul Sehrini Zaptettiler", 29 Haziran 1950; Milliyet, "Kızıllar Güneyin Başşehri Seul'ü İşgal Ettiler", 29 Haziran 1950; Hürriyet, "Kore'de Amerikalılar Kizıllarla Çarpișıor", 5 Temmuz 1950; Zafer, "Kore'de Amerikalıların Ilk Muvaffakiyetleri", 6 Temmuz 1950. "Mc Arthur Baskomutan Oldu", 9 Temmuz 1950. “Kore'de Vaziyet Ámerikalıların Lehine İnkişaf Etmeye Başladı”, 17 Temmuz 1950.

${ }^{6}$ Erkilet, a.g.e., s.1975, s.55-57.

${ }^{7}$ Hürriyet, "Kore'de Kızıllara Öldürücü Bir Darbe İndirildi", 16 Eylül 1950; Ulus, "Birleşmiş Milletler Kuvvetleri Kore'de Inchon Limanı'na Bir Çıkarma Yaptılar",16 Eylül 1950; Hürriyet, "Kızıl Kore Ordusu Tam Bir Bozgun Halinde", 29 Eylül 1950; Ulus, "Kore'de Komünistler Perişan Bir Halde Kuzeye Kaçıyorlar", 29 Eylül 1950. "Mc Arthur Dün Seul'de İdareyi Sivillere Teslim Etti”, 30 Eylül 1950.

${ }^{8}$ Ulus. "Komünist Koreliler Durmadan Cekiliyor", 24 Eylül 1950; Hürriyet,

“Amerikalılar Dün 38. Arz Dairesini aşıp Kuzey Kore Arazisine Girdiler”, 9 Ekim 1950.

"Kızıl Kore'nin Merkezi Pyongyang Dün Düştü”, 19 Ekim 1950

${ }^{9}$ Erkilet, a.g.e., s.62.

${ }^{10}$ Milliyet, "Kore Harbi'ne Son Verecek Taarruz Dün Başladı",25 Kasım 1950. "Kore'de Kızıl Kuvvetler Mukabil Taarruza Geçti”, 27 Kasım 1950.

"Hürriyet, "Kore'de Durum Vehamet Kesbediyor", 6 Aralık 1950.

${ }^{12}$ Milliyet, "Kore'de Kızıl Çin Taarruzu", 2 Ocak 1951, "Komünistler Dün Seul'e Girdiler", 4 Ocak 1951; Zafer, "Seul Terk Edildi”, 5 Ocak 1951,

${ }^{13}$ Hürriyet, "Mütareke Ümitleri Artıyor", 17 Ocak 1951. "Kızıl Cin Tarafından Dün Yapılan Mukabil Teklifleri Kabul Edemeyeceğini Birleşik Amerika Resmen Bildirdi”, 18 Ocak 1951.

${ }^{14}$ Milliyet, "Kızıl Çin Nihayet Dün Mütecaviz İlan edildi”, 1 Şubat 1951. Hindistan, Birmanya ve Rusya aleyhte, Asya ve Arap Devletleri çekimser kaldi. 
yol kalmadı. General Mc Arthur'un yerine 30 Haziran 1951'de BM Ordusu Başkomutanlığı'na getirilen General Ridgway, ateşkes yapılması ve yürütülmesi için görüşme yapabileceklerini açıkladd ${ }^{15}$. Çin'in uygun bulmasıyla görüşmeler Kaesong'de başladı. Ancak, iki taraf da prestij kaybını göze alamadıklarından, özellikle esir değişimini bahane ederek görüşmeleri uzatt1 ${ }^{16}$. Kaesong'da 10 Temmuz 1951 'de başlayan ateşkes görüşmeleri, 27 Temmuz 1953'te Panmunjom'da sonuçland ${ }^{17}$.

Kore Savaşı'nın başlaması, Türkiye'nin de tehdit altında olduğu varsayımıla gündeme geldi. İlk haber ve yorumlara göre; bölgede 1945 'den beri gelişen olaylar yeni bir dünya savaşı ihtimalini arttırmış, stratejik olduğu kadar ekonomik anlamda da önemli olan Kore, ABD-Sovyet çıkarlarının emrinde, kardeş kavgasının esiri olmuş, Dünya Savaşı'nı takip eden dönemin bütün günahı Kore'ye çıkarılmıştı ${ }^{18}$. Sovyetler Birliği tarafından desteklenip kışkırtılan K.Kore Ordusu, ABD tarafından desteklenen G.Kore'ye saldırmıștı. Sovyetler Birliği, Kore dışında bütün Asya kıtasına el atarken, Kore dışında önemli stratejik bölgeye sahip olmayan ABD, Japonya'yı elde tutabilmek için Kore'yi savunmak zorundaydı. ABD, G.Kore'yi ve benzer kaygılarla Sovyetler Birliği de K.Kore'yi silahlandırmıştı ${ }^{19}$. ABD, Kore'ye saldırıyı bir nevi "Pearl Harbour" telaşı ve heyecanıyla karşılamıştı, bölgede ciddi bir çatışmaya girebilirdi ${ }^{20}$. En çok üzerinde durulan, çatışmanın yeni bir dünya savaşı ihtimal ve tehlikesini artırmasıydı ${ }^{21}$.

Kore Savaşı'nın bir dünya savaşına dönüşme ihtimalinin zayıf olduğu, büyük devletlerin elini ateşe sokmaları için yeterli bir sebep olmadığı; Amerika'nın, özellikle Uzakdoğu'da, düşmanlık ve macerayı kabul edemeyeceği, Sovyetlerin amacının ise savaşmak değil, milletleri daimi bir savaş huzursuzluğu içinde bırakmak olduğu ileri sürüldü. Savaş, psikolojik bir çatışma olacaktı ${ }^{22}$. Bölgedeki silahlanma yarışında Sovyetler Birliği, ABD'ye göre daha başarılı olmuş ve ilk raundu kazanmıştı. ABD'nin Kore tecrübesinden ders çıkararak Türk Silahlı Kuvvetlerini acele modernize etmesi bölgedeki hassas dengeler açısından önemliydi ${ }^{23}$.

Kore, TBMM gündemine 30 Haziran 1950 de geldi. Gelişmeler anlatılarak, BM'nin, 27 Haziran 1950 tarihinde üye devletleri yardıma

\footnotetext{
${ }^{15}$ Hürriyet, "Kore'de Kızıllarla Mütareke Şartları",1 Temmuz 1951; Milliyet, "General Ridgway Dün Resmen Mütareke Teklifi Yaptı", 1 Temmuz 1951

${ }^{16}$ Hürriyet, "Kızılların Mütareke Teklifine Cevabı", 2 Temmuz 1951; Zafer, "Dünyanın Beklediği Müjde: Kore Harbi Sona Eriyor”, 2 Temmuz 1951.

${ }^{17}$ Hürriyet, "Kore'de Komünistler Mütarekeye Yanaştılar", 20 Temmuz 1953. "Kore'de Harp Bitti”, 28 Temmuz 1953; Erkilet, a.g.e., s.396-397.

${ }^{18}$ Mücahit Topalak, "Uzakdoğu", Zafer, 28 Haziran 1950; Hikmet Feridun Es, "Asya Yangını", Hürriyet, 27 Haziran 1950.

${ }^{19}$ Mümtaz Faik Fenik, "Dünya Barıș Yine Tehlikede", Zafer, 26 Haziran 1950.

${ }^{20}$ Ali Naci Karacan, "Üçüncü Bir Dünya Harbi mi?", Milliyet, 29 Haziran 1950.

${ }^{21}$ Ömer Sami Coșar, "Kore Harbi", Cumhuriyet, 26 Haziran 1950; Mümtaz Faik Fenik, "Dünya Barışı Yine Tehlikede", Zafer, 26 Haziran 1950; Hürriyet, "İnönü Dünya Vaziyetini İyi Görmediğini Söyledi”, 3 Temmuz 1950.

${ }^{22}$ Mücahit Topalak,"Kore'de Harp", Zafer, 27 Haziran 1950

${ }^{23}$ Abidin Daver, "Kore Harbi'nin Verdiği Ders", Cumhuriyet, 30 Haziran 1950.
} 
çağırdığı, izlenen dış siyasetin bütünüyle BM ideallerine bağlı olduğu ve gelecek taleplerin olumlu karşılanacağı belirtildi. Barışı seven her milletin bu tür saldırgan davranışlara karşı ortak hareket etmesi gerektiği söylendi ${ }^{24}$. "Aç gözlülere cesaret vermemek, onları istemeyerek teşvik etmek gibi hatalara sapmamak, barışçı milletlere düşen bir vazife" idi $^{25}$.

Türkiye'nin, Sovyetler tarafından desteklenen bir saldırıya, BM ile işbirliği kararını süratle alması, dış politikadaki dinamizm ve samimiyet eseri olarak görüldü. Kore kurtulursa milletler ve barış ideali kurtulmuş olacak, başarısız olunursa Kore'de meydana gelen gelişmelerin İran, Türkiye, Yunanistan ve Yugoslavya'da da ortaya çıkması sürpriz olmayacaktı $^{26}$. Türkiye'nin BM'ye üye olduğu için yardıma koşması gerektiği, yardımın şeklinin "sembolik" olacağı, Asya'nın öbür ucuna asker gönderilmesinin söz konusu olamayacağı genelde savunulan görüștü. Savaşın Türkiye ile ilgisi yoktu ${ }^{27}$. Buna karşın, kağıt üzerinde platonik ve nazari bir yardım olamayacağı, "yarın taarruza uğradığımız zaman bize de bilmukabele sembolik yardım yapılmasına kapı açmış oluruz" 28 görüşü de savunuldu. Her saldırgana ABD kalkan olacak, Türkiye hür milletler safında mücadele edecek, gelişmeler Türk-Amerikan yakınlaşmasını sağlayacak ve silah yardımı artacaktı ${ }^{29}$.

Türkiye'nin, BM ideallerine bağlı bir politika izleyeceği sıklıkla vurgulandı. Ortak düşünce; Sovyetler Birliği'nin Kore'de kışkırtıcı ve saldırgan olduğu, benzer saldırının Türkiye'ye de yapılabileceğiydi. Türkiye'nin Kore'ye asker göndermesi bu aşamada mümkün görülmemekteydi.

Hükümet 25 Temmuz 1950 de, bir Türk savaş birliğini BM emrine vermeyi kararlaştırdı. Asker gönderme kararının, TBMM ve siyasi parti görüşleri alınmadan açıklamasına CHP ve Millet Partisi benzer tepkiler verdi: Partilerle görüşülmemesinin önemli bir eksiklik olduğu, Meclisten onay almayarak daha da büyük hata yapıldığ $\breve{1}_{1}$, Türk askerinin sadece Türkiye sınırlarını korumakla yükümlü olduğu ve yurtdışına birlik göndermek için mutlaka Meclisten onay alınması gerektiği savunuldu ${ }^{30}$

${ }^{24}$ TBMM Tutanak Dergisi; IX/C:1, s.312; Hürriyet, "Türkiye Kore İşinde Üzerine Düşen Vecibeleri Yapacak", 1 Temmuz 1950; Milliyet, "Hür Milletleri Biz de Destekliyoruz", 1 Temmuz 1950.

${ }^{25}$ Nadir Nadi, "Karar", Cumhuriyet, 1 Temmuz 1950.

26"Mümtaz Faik Fenik, "Türkiye'nin Dünya Barısına Hürmeti", Zafer, 1 Temmuz 1950, Cumhuriyet, "Kore Harbi'nde Tek Çıkar Yol", 21 Temmuz 1950; Necmettin Sadak, "Hazırlıksız Olunca", Akşam, 19 Temmuz 1950.

${ }^{27}$ Sedat Simavi, "Amerika'ya Türk Yardımı", Hürriyet, 2 Temmuz 1950. "Kore Harbi ve Kriz", 15 Temmuz 1950; Necmettin Sadak, "Kore Savaşı ve Türkiye”, Akşam, 6 Temmuz 1950

${ }^{28}$ Abidin Daver, "Konsey'in Kararı ve Türkiye”, Cumhuriyet, 8 Temmuz 1950

${ }^{29}$ Akşam, "İkinci Truman Doktrini", 25 Temmuz 1950; Milliyet, "İstanbul'da Kore İçin Gönüllüler", 3 Temmuz 1950; Hürriyet, 4 Temmuz. 1950; Hürriyet, "Köprülü Kore Harbi Hakkında İzahat Verdi", 5 Temmuz 1950.

${ }^{30}$ Hükümetin, 18 Temmuz 1950'de Yalova'da gizli bir toplantı yapması, Türkiye'yi ilerleyen günlerde önemli gelişmelerin beklediği şeklinde algılandı. Milliyet, "Yalova'da 
Hükümet, Türk askerinin BM emrinde oluşturulmuş uluslararası birlikte görev yapacağı, herhangi bir devlete savaş açmadığı ve Meclis onayının gerekmediğini açıklandı. BM Anayasasının, Hükümete bu tip konularda karar alma hakkı tanıdığını iddia etti. Muhalefete göre, büyük ülke sorunlarında, özellikle ülke savunması ve savaş ihtimallerinde hükümetin muhalefetle işbirliği sağlaması esastı. Düzenli askeri kıtalarla barışı sağlamak için girişilen silahlı çarpışmaya savaştan başka bir ad verilemezdii ${ }^{31}$. MP Genel Başkanı Hikmet Bayur, karardan memnun olmayan kişilerin komünistlik suçlamalarıyla alçaltılmak istendiğini iddia etti. Türkiye'nin güvenliği için NATO'ya biran önce girmemiz gerektiğini, milletçe katlanılan fedakarlığın ve askerlerin akacak kanlarının, siyasal bakımdan ülke lehine fayda getirmesini, Hükümetin, dışardan bir miktar yardım sağlayıp bütçe açığını kapatmaya çalışarak başarı kazandım havasına girmesini Türk halkının affetmeyeceğini ${ }^{32}$ söyledi. Karşı çıkılan, Kore'ye asker gönderilmesinden çok, düşüncelerin ve Meclis onayının alınmamasına idi.

Basın, Türkiye'nin Kore savaşına fiilen katılma kararında büyük ölçüde hükümeti destekledi. Hükümetin bu kararı, "sırf hürriyet ve barış dünyasına karşı beslediği bağlılık duygusundan” aldığı kaydedildii ${ }^{33}$. Kore'de dünya barışının geleceğinin söz konusu olduğu, BM ülküsü mağlup olursa, saldırganın Türkiye'ye de yönelebileceği iddiası yenilendi. Türk askerleri, Kore'de hem dünya güvenliğini hem de Türk sınırlarını koruyacak, yarın olası bir saldırı karşısında yalnız kalmaktan kurtulacaktı ${ }^{34}$.

Sovyetler Birliği'ni tahrik edeceği iddiasına karşılık; Türkiye'ye saldırmaya niyetli ise nedenler bulmakta güçlük çekmez düşüncesi savunuldu. Sovyetler, Kore Savaşı'na fiilen müdahale etmişti. Türkiye'nin stratejik konumu G.Kore'den çok daha önemli olduğuna göre, saldırıya uğradığımız takdirde bizim de yardım göreceğimizi kabul etmek gerekirdi ${ }^{35}$. Konunun TBMM'ye getirilmesi, dış politika geleneği olmakla birlikte zorunluluk değildi. Türkiye Kore'ye savaş ilan etmemiş, BM katındaki yükümlülüklerini yerine getirmişti ${ }^{36}$. Hükümetin tecrübesizlik ve acemilikten dolayı bir hata yaptığı, kararda Meclisin ve muhalefetin oyu bulunsaydı, "sızıltının ve mırıltının daha hafif olacağı", ancak anlayışla karşılamak gerektiği düşüncesi farklı ifadelerle ve sıklıkla vurgulandı. Meclis onayının almasının kararı kuvvetlendireceği ifade edildi. Hükümetin pazarlıkla,

Mühim Toplantı", 19 Temmuz 1950; Nihat Erim, "Hükümetin Son Kararı", Ulus, 27 Temmuz 1950.

${ }^{31}$ Hürriyet, "Inönü'nün Hürriyet'e Beyanatı”, 28 Temmuz 1950. “Kasım Gülek Başbakanın Dün Yaptığı Beyanata Cevap Verdi”, 30 Temmuz 1950.

${ }^{32}$ Hikmet Bayur, "Küçük Marifetler ve Büyük İşler", Kudret, 1 Ağustos 1950

${ }^{33}$ Nadir Nadi, "Hükümetin Kararı", Cumhuriyet, 27 Temmuz 1950.

${ }^{34}$ Mümtaz Faik Fenik, "Kore'ye Gidecek Türk Askerleri Yolunuz Açık Olsun", Zafer, 27 Temmuz 1950.

${ }^{35}$ Abidin Daver, "Kararımız İsabetli mi, Değil mi?", Cumhuriyet, 28 Temmuz 1950; Burhan Belge, "Stalin Durmasını Bilir mi?", Yeni Sabah, 27 Temmuz 1950.

${ }^{36} \mathrm{Nadir}$ Nadi, "Haklı ve Haksız", Cumhuriyet, 29 Temmuz 1950. 
ABD'ye NATO'ya alınmak gibi bir takım şartlar öne sürerek Kore'ye asker gönderme kararı verdiği iddiaları ile iç politika malzemesi yapılması eleștirildi. Türk dış politikasında ayrılık olduğu izleniminin oluşturulması ülke çıkarlarını zedelerdi ${ }^{37}$. Siyasetçilere düşen görev, birlik ve beraberlik havasını bir an bile bulandırmamaktı. Kararın tarihin derinliklerindeki Türk kahramanlığını yeniden canlandıracağı, askerlerimizin "maddiyatçı Moskof saldırı ruhunu ve komünizmin maskeli yıkıcı kuvvetlerini yeneceği”, Meclis toplantısı, usul, şekil, pazarlık diye ortaya atılan bahanelerin, tarihi rolümüze karșı girişilmiş bir bozgunculuk olduğ ${ }^{38}$ da iddia edildi. Türkiye'nin mertçe yardıma rağmen Marshall Planı'ndan "devede kulak kabilinde" yardım aldığı, ABD'nin daha fazla yardım yapması gerektiğ $i^{39}$ gündeme getirildi.

Karara en sert tepki Barışseverler Derneği'nden geldi. Temel düşüncesi; asker gönderme kararının anayasal geçerliliğinin olmadığ 1 ve BM ile bu konuda herhangi bir anlaşma yapılmadığı idi. Dernek ve girişimi; kökü dışarıda "komünizm propagandası", "memleketi içten yıkmaya çalışan tahrik ve fesat ocağı" olarak suçlandı. Adli soruşturmalar ve mahkumiyetler girişimi etkisizleş̧irdi ${ }^{40}$.

Kore Savaşı ve Kore'ye asker gönderme kararı ile ilişkilendirilen konuların başında Türkiye'nin güvenliği bağlamında ABD ile ilişkiler ve NATO yer aldı. Türkiye'nin NATO'ya kabul edilmemesi; NATO ve üye ülkeler ile birlikte, Kore'ye asker gönderilmesinin de sorgulanmasına yol açtı.

NATO, Kore Savaşı öncesi kamuoyunda olumlu ancak farklı değerlendirildi. Kabul gören, Sovyet yayılmacılı̆̆ını Avrupa'da önlemek için kurulmuş bir güvenlik sistemi olduğu idi. Türkiye'nin coğrafi nedenlerden dolayı NATO'dan "geçici” dışlanması ve bir Akdeniz Paktı belirsizliğine itilmesi rahatsızlık yarattı. Tarafsız politika izlenmesinin daha yararlı, hatta bir III. Dünya Savaşında, Türkiye'nin lehine olabileceği, saldırganın yönünü değiştirilebileceği düşüncesini geliştirdi.

Kore'ye asker gönderme kararı sonrası başvuru, Türkiye'nin NATO'ya alınacağı izlenim ve ümidini doğurdu ${ }^{41}$ : Kore olayının Batılıların gözünü

${ }^{37}$ Sedat Simavi, "Mintarafillah", Hürriyet, 31 Temmuz 1950; Necmettin Sadak, "Türkiye'nin Kore'ye Yardımı", Akşam, 9 Ağustos 1950; Ali Naci Karacan, "Eğer Akılları Olsaydı", Milliyet, 4 Ağustos 1950; Yeni Sabah, "Bozguncu Cereyanlar”, 1 Eylül 1950; Adnan Adıvar, "Bir Buçuk Asırdan Beri...", Aksam, 2 Eylül 1950.

${ }^{38}$ Ahmet Emin Yalman,"Türkler Geliyor", Vatan, 3 Ağustos 1950.

${ }^{39}$ Hüseyin Cahit Yalçın, “Amerika'nın Yerinde Bir Kararı", Ulus, 3 Ağustos 1950.

${ }^{40}$ Zafer, "Başbakan Tenkitlerin Yersizliğini Belirten Beyanatta Bulundu", 29 Temmuz 1950; Hürriyet, "Köprülü Kore'ye Asker Sevki İşinde Tenkitleri Reddetti”, 31 Temmuz 1950; Ali Naci Karacan, "Bozguncuları Tasfiye Zamanı Gelmiştir", Milliyet, 1 Ağustos 1950; Zafer, "Behice Boran ve Üç Suç Ortağı Tevkif Edildi”, 30 Temmuz 1950.

${ }^{41}$ Hürriyet, "Atlantik Paktına Girmek İçin Resmen Müracaatta Bulunduk", 3 Ağustos 1950; Zafer, "Atlantik Paktına İştirakimiz İçin Amerika'nın Derhal Siyasi Hazırlıklara Girmiş Olduğu Haber Veriliyor", 4 Ağustos 1950; Ömer Sami Çoşar, "Türkiye ve Atlantik Paktı", Cumhuriyet, 3 Ağustos 1950; Milliyet, "Başbakan Adnan Menderes'in Çok Mühim Beyanatı", 7 Ağustos 1950 
açtığı, aldıkları dersle Türkiye'nin NATO'ya girmesine muhalif kalmayacakları düşünüldü. Başbakan, Türk dış politikasının İngiliz-Fransız ittifakına ve Amerikan dostluğuna dayandığını, NATO'ya girme çabaları ve Kore'ye asker gönderme kararının barışı korumak için yapıldığını açıkladı.

Türkiye'nin, NATO'ya alınmama gerekçesi olarak ileri sürülen coğrafi nedenler geçerliliğini yitirmiş, Kore Savaşı Türkiye'nin pakta katılması gerekliliğini ortaya çıkarmıştı ${ }^{42}$. NATO'yu kuran devletlerin kaygıları Türkiye için de geçerliydi. Türkiye'nin katılımıyla, komünist saldırılar karşısında endişeye düşen dünya yeniden birlik olacakt ${ }^{43}$. Kore'ye savaş birliği gönderme kararıla, NATO'ya üye olmaya en çok hak kazanan ülke olmuştu. Sürüncemede bırakılması ABD'nin olduğu kadar NATO'ya üye devletlerin de itibarını sarsacak, Türk kamuoyunu rencide edecekti ${ }^{44}$.

12 Eylül 1950 tarihinde "Üçler Konferansı"nda Türkiye'nin, "şimdilik" Pakt'a alınmaması kararı kırgınlık ve kızgınlık yarattı ${ }^{45}$ : Fenik, önemli askeri gücü ile Ortadoğu petrollerini koruyan ve "komünist saldırılarına karş1 dalgakıran" olan Türkiye'nin gözden uzak tutulmasının tarihi bir hata olacağını anlattı. Coğrafi yaklaşımı "mesnetsiz" buldu. Asıl sözün ABD ve İngiltere tarafından söylendiğini, diğer devletlere kabul ettireceklerini savundu $^{46}$. Sadak, NATO'ya giriş başvurusu ile Kore'ye asker gönderme kararı arasında ilişki kurmanın sağlıklı bir değerlendirme olamayacağı ve ulusal davaların sonuna kadar savunulması gerektiği düşüncesindeydi. Türkiye'nin, ABD'ye ihtiyacı olduğu kadar, ABD ve Batılı ülkelerin de Türkiye'ye ihtiyacı vardı. Çă̆ıracakları güne kadar sabredilmeliydi. Doğu Akdeniz Paktı gibi yaklaşımlar yeterince aydınlık değildi. Türkiye Akdeniz'den değil, başka bölgelerin tehdidi altında idi ${ }^{47}$. Simavi, başta Fransa olmak üzere bütün Avrupa'yı "Haçlı Zihniyeti" taşımakla suçladı. Türkiye'nin "Müslüman" olmasının gerekçe olup olmadığını sordu. "Komünizm tehlikesi karşısında Avrupa'nın müdafaa edileceğine" inanmadığını belirtti ${ }^{48}$. Karacan, kararın Türkiye'yi etkilememesini, Türkiye'nin, BM sözleşmesindeki yükümlülüklerini yerine getirmek için Kore'ye bir an önce gidip, gerekirse kan akıtarak fedakârlıkta bulunabileceğini, "alacağımız en dürüst, en güzel, en tesirli vaziyet ancak askeri birliğimizi bir an evvel yola çıkartmaktan ibaret" ${ }^{\text {"49 }}$ olduğunu savundu.

\footnotetext{
${ }^{42}$ Mümtaz Faik Fenik, "Türk Gücü ve Barış İdeali”, Zafer, 7 Ağustos 1950.

${ }^{43}$ Hüseyin Cahit Yalçın, "Atlantik Misakında Türkiye", Ulus, 9 Ağustos 1950.

${ }^{4}$ Sedat Simavi, "Atlantik Paktı ve Türkiye", Hürriyet, 27 Ağustos 1950; Hürriyet, "Atlantik Paktına Girmek İçin Yaptığımız Talep", 26 Ağustos 1950.

${ }^{45}$ Sedat Simavi, "Türkiye ve Atlantik Paktı", Hürriyet, 14 Eylül 1950.

${ }^{46}$ Mümtaz Faik Fenik, "Türkiye İçin Sağlam Teminat", Zafer, 14 Eylül 1950. "Atlantik Paktı ve Vaziyetimiz", 17 Eylül 1950. "Atlantik Paktı, İngiltere ve Fransa”, 21 Eylül 1950.

${ }^{47}$ Necmettin Sadak,"Atlantik Paktı ve Türkiye", Akşam, 15 Eylül 1950. "Üçlerin Kararından Sonra”, 17 Eylül 1950. "Atlantik Paktı, Doğu Akdeniz Müdafaası ve Türkiye'nin Emniyeti", 24 Ocak 1951.

${ }^{48}$ Sedat Simavi, "Beğendiniz mi Olanı”, Hürriyet, 16 Eylül 1950. "Avrupa'nın Müşterek Müdafaasına İnanmıyoruz", 18 Eylül 1950.

${ }^{49}$ Ali Naci Karacan, "Kore'ye Biran Önce Gitmeliyiz", Milliyet, 18 Eylül 1950.
} 
Emeç, Sovyetler Birliği'ni tahrik etmemek için Türkiye'yi pakta kabul etmemenin bahane olduğunu, başvurunun zamansız yapıldığını belirtti ${ }^{50}$.

Hükümetin Kore'ye asker gönderme kararı üzerine, Genelkurmay Başkanlığı, 3 Ağustos 1950 de 4500 kişilik savaş birliğinin hazırlanmasını emretti. Komutanlık karargâhıyla gerekli birliklerden meydana gelecek bir tugay olması kararlaştırıldı. Erlerin, 1929 doğumlu ve gönüllülerin tercih edilmesi, işlemlerin 20 Ağustos 1950'ye kadar bitirilmesi istendi" "Kore Bürosu" kuruldu ${ }^{52}$.

Tugay, 19-20 Eylül 1950 tarihinde, 259 subay, 18 askeri memur, 4 sivil memur, 395 astsubay ve 4414 er olmak üzere toplam 5090 kişilik dört katarla İskenderun'a hareket etti. Bağlantı kurmasına yardımcı olmak üzere beş kişilik bir Amerikan irtibat grubu da İskenderun'a gitti ${ }^{53}$.

Tugayı, Kore'ye ulaştırmak için BM adına üçü personel, ikisi araçgereçler için beş gemi -ABD tarafından- hazırlanmıştı. İlk kafile 25 Eylül, ikinci kafile 26 Eylül; üçüncü kafile 29 Eylül; araç-gereç gemileri de 30 Eylül ve 2 Ekim 1950 'de yola çıtı ${ }^{54}$. Yolculukta, ABD silahlarıyla eğitim yapıldı. "Kore Yolu" adlı gazete çıkarıldı. 18-19-20 Ekim 1950 de Pusan rıhtımına ulaşan birlikler, Taegu şehrinde 20 gün kaldı. Dağlarda gizlenen ve fırsat buldukça saldıran çeteleri arayıp temizlemek, yol ile köprülerin güvenliğini sağlamakla görevlendirildi ${ }^{55}$.

Türk birliklerine, cephedeki Amerikan kolordusunun ihtiyatı olmak üzere, 18 Kasım 1950'de Kunuri bölgesine hareket etmesi emri verildi. Motorlu ve yaya birlikleri kendi imkanlarıyla 23-26 Kasım'da bölgeye ulaştı. Çin hücumu ve kuşatılma tehlikesine karşılık verildi, süngü savaşı yapıldı $^{56}$. Dost ve düşmanın kim olduğu henüz ayırt edilemeyen sarp arazide, üstün sayıda ve akıcı bir düşmana karşı girdiği savaşta Çin ileri harekatını geciktirdi. Kunuri - Sunchan arasındaki boğazda zaman zaman yok edilmek

\footnotetext{
${ }^{50}$ Selim Ragıp Emeç, "Yine Atlantik Paktı Hikayesi”, Son Posta, 22 Eylül 1950.

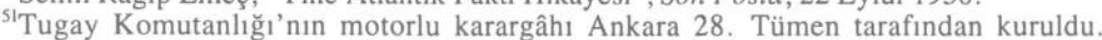
Aynı tümenin Ayaş'ta bulunan 241. Piyade Alayı, Türk Tugayı'nın piyade alayını, Etimesgut'taki 2. Zırhlı Tugay 2. Motorlu Topçu Taburu da tugayın motorlu topçu taburunu oluşturdular. BM Kore Türk Tugayı Komutanlığına Tuğgeneral Tahsin Yazıcı ve Kurmay Başkanlığına Kurmay Yarbay Selahattin Tokay, Alay Komutanlığı'na Celal Dora atandı. Hürriyet, "Kore'ye Gidecek Alayımız dün Merasimle Ayaş'tan Ayrıldı", 9 Ağustos 1950; Zafer "Kore'ye Gidecek Yiğitler Dün Ayaş'taki Karargahtan Ayrıldılar", 9 Ağustos 1950.

${ }^{52} H u ̈ r r i y e t$, "Kore'ye Gidecek Kıtalarımız Dün Teftiş Olundu", 19 Eylül 1950; Doğan, a.g.t., s.28-29. Gazeteciler, fotoğraf ve film çektiler, yazılar yazdılar. Kore Marșı söylendi.

${ }^{53}$ Erkilet, a.g.e ,s.72. Topçu Albay Gumby'nin başkanlığında, üyeleri Piyade Kurmay Yarbay Wedwer, istihkâm Binbaşı Munsin, Ordu donatım Subayı Robenson ve Muhabere Yüzbaş Lorenzo'dan oluşmakta idi.

${ }^{54}$ Hürriyet, "Kore Savaş Birliğini Uğurladık", 28 Eylül 1950; Ulus, "Kore'de Savaşacak Birliğimiz Yola Çıktı", 29 Eylül 1950.

${ }^{55}$ Hürriyet, "Kore Birliğimizin Bir Kısmı Dün Pusan Limanı'nda Karaya Çıktı", 19 Ekim 1950. "Kore Savaş Birliğimiz Taegu Şehrine Yerleşti”, 26 Ekim 1950; Milliyet, "Kore Birliğimiz Savaşa Başladı", 8 Kasım 1950.

${ }_{56}$ Hürriyet "General Mc Arthur Kore Birliğimizi Tebrik Etti”, 19 Kasım 1950. "Kore'de Kızıl Çinliler Hücuma Geçtiler", 27 Kasım 1950; Ulus, "Kore'de Durum”, 27 Kasım 1950; Milliyet, "Birliğimizin Parlak Muvaffakiyeti", 29 Kasım 1950.
} 
tehlikesi altında savaşarak kendine yol açarken; boğazda sarılmış olan Amerikan Tümen Karargâhının kurtulmasına da yardım etti. "Gönüllüler" adıyla organize olan Çinlilerin başlattıkları büyük saldırı, BM Ordusunu şoka sokmuştu. Cephedeki durumun iç açıcı olmadığı, savaşı sona erdirme düşüncesinin tehlikeye girdiği ifade edildi. Amerikan Karargâhının ümit kestiği, Çinliler tarafından sarılan birliğimizin süngü hücumu ile çemberi yararak büyük bir zafer elde ettiği duyuruldu. "Çin artık harp ilan etmeden bilfiil savaşın içindedir" yorumu ile Türk Tugayının destan yarattığı, kaybının az olduğu bildirildi ${ }^{57}$. Süngü savaşlarında Çinlilere karşı ayakta kalabilen sadece Türk kuvvetiydi. Kahramanlığı ve beş misli düşmana karşı bir adım gerilemeden savaşması övüldü. Askerlerin yaralı arkadaşlarını sırtlarında taşıyarak çekilmeleri, güç koşullardan başarıyla çıkmaları anlatıld ${ }^{58}$. Kars'1 Edirne'yi savunur gibi, şehit rütbesine erişmeyi dahi göze alıp savaşmaktaydı. Silahlarını insanlı̆̆ı ve barışı korumak için kullanmışlardı ${ }^{59}$.

Mehmetçiğin başarısı Türkiye'yi gözyaşına boğmuş; Türk, Amerikalı, İngiliz silah arkadaşları insanlık davasının ortak savunucuları olmuş, barış ve refah ideali uğruna kanları birbirine karışmışt ${ }^{60}$. Muhteşem savaşları TürkAmerikan ilişkilerini olumlu yönde geliştirmiş, Amerikan Ordusu dışında savaşan 14000 askerin üçte birinin Türk askeri olması, Türklerin Amerikalılarca daha iyi anlaşılmasına neden olmuştu ${ }^{61}$. Türkiye'nin dünya barışına verdiği değer Amerika kamuoyu tarafından da kavranmış, gelen ışık yurdumuzu aydınlatmıștı. Bu kadar zamandır kahramanlığını gösterme fırsatı bulamayan Türk askeri aradığını Kore'de bulmuștu' ${ }^{62}$. Yurduna göz diken düşmanlara mesaj vermiş, kendilerini feda ederek BM'nin 8. Ordusu'nu kurtarmıştı. Ancak, Avrupa'nın kayıtsızlığı BM'yi ölüme sürüklemekteydi ve çöküşü Türk askeri tek başına durduramazdı ${ }^{63}$.

Kunuri başarısı üzerine Tugaya takdir, sevgi ve şükranlar bildirildi. Türkiye'nin her yerinde miting ve toplantılar düzenlendi, tebrik telgrafları çekildi. Ankara ve İstanbul'da yapılan mitinglerde, Kore'de şehit düşen askerler için saygı duruşunda bulunulup, komünizme karşı mücadelede savaşa hazır olunduğu belirtildi ${ }^{64}$. Dini terminoloji kullanıldı. Diyanet İşleri

${ }^{57}$ Milliyet, "Kore'de Kızıl Kuvvetler Mukabil Taarruza Geçti”, 27 Kasım 1950; Zafer, "Kore'de Günün Tek Zaferini Tugayımız Kazandı", 29 Kasım 1950; Hürriyet, "Kore'de Türk Askerinin Büyük Zaferi”, 29 Kasım 1950. "Kore'deki Birliğimiz Destan Yaratıyor”, 30 Kasım 1950

${ }_{58}$ Ulus, "Tugayımız Kahramanca Dayanıyor", 30 Kasım 1950; Zafer, "Kore Birliğimizin Kahramanlığı", 30 Kasım 1950; Milliyet, "Mehmetçik Yaralıları Sırtında Taşıyarak Pyongyang'a Çekildi", 2 Aralık 1950.

${ }^{59}$ Mümtaz Faik Fenik, "Kore'de Savaşan Kahramanlarımıza”, Zafer, 30 Kasım 1950. "Kore'deki Kahramanlarımız", 2 Aralık 1950.

${ }^{60}$ Hüseyin Cahit Yalçın, "Mehmetçiklerimiz", Ulus, 3 Aralık 1950

${ }^{61}$ Abidin Daver, "Amerika Türkiye'ye Minnettardır", Cumhuriyet, 4 Aralık 1950.

${ }^{62}$ Peyami Safa, "Kore'den Gelen Isık", Ulus, 7 Aralık 1950.

${ }^{63}$ Asım Us, "Birleşmiş Milletler Müessesi Yaralıdır", Vakit, 31 Aralık 1950.

${ }^{64}$ Milliyet, "Basbakanın Kahramanlara Mesaj1", 3 Aralık 1950. "Meclis Kahramanlarımıza Yeniden Sükranlarını Bildirdi”, 5 Aralık 1950; Ulus, "Her Yerde Mitingler Yapılıyor", 4 Aralık 1950; Hürriyet, "Dün Kore Şehitleri Tazimle Anıldı",10 Aralık 1950. 
Başkanı, Kore'deki savaşın inananlarla inanmayanlar arasında geçtiğini, inananların zafer kazanacaklarına inandığını belirtti. İslamiyet'in komünizmi reddettiğini ifade eden Başkanlık, "Kore'nin Allah yolu" olduğunu ve hayatlarını kaybedecek Mehmetçiklerin şehit sayılacaklarını fetva yoluyla bildirdi ${ }^{65}$. Kore'de savaşan askerlerin Türk vatanını, sınırını ve dinini koruduğu sıklıkla vurgulandı.

Kutlama, destek mitingi ve gösterilere rağmen, birliklerin ateş altında kalması ve verilen kayıplar muhalefeti harekete geçirdi. Kemal Türkoğlu ile Osman Bölükbaşı, 11 Aralık 1950 de TBMM gündemine gelen gensorularında; Hükümetin bir emrivaki ile Kore'ye birlik gönderme kararı verdiğini ve kararı TBMM'de onaylatmayarak yasa dışı girişimde bulunduğunu ileri sürdüler. Tartışma sonrası verilen önerge ile Kore'ye asker gönderilmesi kararı onaylandı ${ }^{66}$.

Kunuri'den sonra, K.Kore Ordusunun gerilla desteği ile bütün hatlarda tekrar hücuma geçmesi üzerine çekilmek zorunda kalan BM Ordusunun kuşatılmasına engel olma görevi Türk Tugayı'na verildi ${ }^{67}$. Kumyongjangni'de yapılan savaşta, berkitilmiş ve inatla savunulan arazi ele geçirildi. Türk birlikleri savaşı kazand ${ }^{68}$.

Yaralı askerler, 8 Ocak 1951 'den itibaren yurda dönmeye başladı ${ }^{69}$. ABD'nin Türkiye'yi sağlam bir müttefik olarak görmesi sonucunu doğuran Kore'deki Türk kanının, vatan için aktığına hiç şüphe olmadığı ifade edildi. Türk ve Amerikan gençlerinin kanlarıyla özgürlük idealine büyük katkıları olduğunun altı çizilip, iki ülke arasındaki birlik sonucu Yakın Doğu medeniyet kalesinin kolay düşmeyeceği vurguland ${ }^{70}$. Kunuri zaferinin üzerinden üç buçuk ay geçmesine rağmen NATO konusunda olumlu adım

${ }^{65}$ Milliyet, "Süleymaniye Camiinde Şehitler Muazzam Dini Merasimle Anıldı", 11 Aralık 1950

${ }^{66}$ Bölükbaşı, yetkinin Meclis'e ait ve tartışılmasının zorunlu olduğunu, Türkiye'nin bu tarz bir yardım yapma yükümlülüğünün olmadığını savundu. Hükümeti Anayasaya uymamakla ve BM Antlaşması'nı yanlış yorumlamakla suçladı. Türkoğlu, üç soru yöneltti: Kore'ye asker gönderilmesi için Bakanlar Kurulu'nca alınmış bir karar var mıdır? Karar alınmışsa ittifakla mı alınmıştır?". "Birliğin mevcudu standart mıdır?" BM üyesi olan devletler fiilen Kore'ye savaş birliği göndermişler midir? Her birinin miktarı ne kadardır?"

Menderes, ittifakla alınan Kore kararının muhalefetin dilinde bir Yemen örneği olarak ele alınarak kamuoyunun tahrik edilmeye çalışıldığını ve birliğin standart olduğunu söyledi. DP Milletvekili Muhittin Erener, muhalefetin yeni bir Yemen açıldığı, Türk evlatlarının yabancı illerde telef edileceği, İnönü'nün bu milleti savaştan kurtardığı, DP iktidara geçer geçmez savaş ilan olunduğunu, Kore'de ölen askerler şehit olur mu olmaz mı gibi ifadelerle halkı tahrik ettiklerini, kamuoyunun bu tahriklere kapılmadığını belirtti. TBMM Tutanak Dergisi, IX/C.1, s. 136-137,140-143,151-152,167-176,185,201; Milliyet, "Kore Kararı İçin verilen Gensoruda, Hükümet Kahir Ekseriyetle İtimat Oyu Aldı", 12 Aralık 1950

${ }^{67}$ Hürriyet, "Tugayımı Tekrar Harbe Giriyor", 11 Aralık 1950.

${ }^{68}$ Milliyet, "Kore Birliğimiz Harikalar Yarattı", 29 Ocak 1951; Hürriyet, "Kore'de İleri Harekat İnkişaf Ediyor", 30 Ocak 1951; Amerikan Kongresi, Türk Tugayına "Mümtaz Birlik" nişanı verilmesini kararlaştırdı. Bu nişanı alan ilk yabancı birlik Türk Tugayı oldu

${ }^{*}$ Cumhuriyet, "Kore'den ilk yaralı kafilesi dün uçakla şehrimize geldi - 18 kahramandan ibaret olan yaralılar Yeşilköy'de karşılanarak Deniz hastanesine yatırıldılar-”, 9 Ocak 1951.

${ }^{70}$ Hüseyin Cahit Yalçın, "Türk-Amerikan Yakınlığı”, Ulus, 27 Ocak 1951. 
atılamaması eleştirildi.“...Kore'de döktüğümüz kanın karşılığını maalesef göremedik... Kore'deki fedakârlığımız bize Atlantik Paktı'nın kapılarını bile açmadı" "71.

ABD'nin, Türkiye ve Yunanistan'ın NATO'ya alınmaları teklifine müttefiklerinden itirazlar geldi. İtirazlar daveti geciktirince Batı, "gaflet içinde" olmakla suçlandı ${ }^{72}$. Sadak, Türkiye'nin NATO'ya alınmasının zor olduğu, gelişmeler ışığında NATO'nun Türkiye'ye tek taraflı ağır külfetler yükleyeceği, ordusundan yararlanmaya kalkışacağı, işin peşini bırakmanın daha iyi olacağını savundu. İngiltere, Akdeniz Paktı ile Ortadoğu'daki çıkarlarını korumak için Türkiye'yi nüfuzuna alet etmek istemekteydi. Dikkatli olunmalıyd ${ }^{73}$.

Simavi, NATO ve ABD'yi geç kalmakla suçladı. Şimdiye kadar bize önem vermeyen Amerika bizi "babasının hayrı" için düşünmüyordu. Bizi, İran'da beliren Rus tehlikesi, dolayısıyla Türk askerine ihtiyaç olacağı için hatırlamıştı. Sıkışınca hatırlamaları bizim için hiçbir şey ifade etmezdi: "Kore yeter. Türklerin kendi hudutları haricinde artık akıtacak kanları yoktu". Artık dost ve düşmanın belli olduğunu belirterek, İtalya ve ABD dışındaki devletlerin tutumlarını eleştirdi. Türkiye'nin en kara günlerinde İngiltere ve Fransa tarafından yalnız bırakılmıştı ve bu kamuoyunca affedilmeyecekti. Türkiye, tarafsızlık politikası izlemeliydi. NATO, Akdeniz Paktı gibi bir pakta girmek zarar hanesini çoğaltacaktı. Kendi askeri gücümüze dayalı tarafsız bir politika daha yararlı olacaktı. Kore Savaşı'ndan ders alıp, hayırsız dostların gönüllerini hoş etmek için dökülen kanlar artık dinmeli, bundan sonra dünya yerinden oynasa Türkiye kılını kıpırdatmamalıydı ${ }^{74}$ : "Bize yabancı bir harbe niçin girdik? Türk'ün cengâverliğini mi dünyaya yaymak istedik? Parlak vaatlere mi kapılıp işe karıştık? Hiçbiri değil... Dışişleri, Türk askerlerinin Kore Harbi'ne karışmalarıyla bizim de büyük devletler arasında reyimiz olacağını zannetti... Zannettiler ki, dünyanın öbür ucundaki bir çarpışmaya iştirak eder etmez, bütün kapılar bize açılacak, NATO bizi hemen içine alıverecek ve Amerikan dolarları memleketimize akacak..." Batılılar, Müslüman bir ülke olan Türkiye'yi, dinsel farklılığından aralarında görmek istememekteydi.

${ }^{71}$ Hikmet Bil, "Son Fırsat", Hürriyet, 15 Şubat 1951; Hükümet, Türkiye'nin, Rusya veya başka bir devletin saldırısına uğradığı takdirde Amerika'nın silahla yardım edeceğine dair bir belgeyi imzalamasını istedi. Amerikan desteği Türkiye için hayati önem taşıyordu. Hürriyet, "Amerika'ya İttifak teklifinde Bulunduk", 3 Mart 1951; Şükrü Kaya, "Türkiye Hâlâ mı Yalnız", Hürriyet, 6 Mart 1951

${ }_{72}$ Abidin Daver, "Türkiye'nin Emniyeti", Cumhuriyet, 9 Nisan 1951.

${ }^{7}$ Necmettin Sadak, "İstemiyoruz Diye Bağırıp İlan Etmemiz Çok Yerinde Olacaktır", Akşam, 6 Nisan 1951. "Türkiye ve Atlantik Paktı", 25 Nisan 1951. "Ortadoğu Müdafaası Hakkında İngiliz Teklifi ve Türkiye'nin Menfaatleri”, 16 Ağustos 1951.

${ }^{74}$ Sedat Simavi,"Geç Kalan Bir Davet", Hürriyet, 18 Mayıs 1951. "Artık Anlaşıldı", 3 Haziran 1951. "Silahlı Bitaraflık", 19 Haziran 1951. "Türk'e Saygı", 3 Temmuz 1951. 
Kore'den ders alıp bir daha böyle işlere bulașılmamalı, Türk çocukları ulusal sınırlar dışındaki "sergüzeştlere" gönderilmemeliydi ${ }^{75}$.

Ortadoğu'da siyasi havanın bulanması, İran buhranı, itirazları azalttı. NATO Bakanlar Konseyi, 16-20 Eylül 1951 tarihinde Türkiye ve Yunanistan'ın üye olarak çağrılmalarına karar verdi. Davetin Türk süngüsüyle geldiği, Kore'deki dillere destan zaferler gerçekleşmeseydi kimsenin NATO'ya çă̆ırmayı aklına getirmeyece ğ $\mathrm{i}^{76}$, gerginleşen Amerikan-Sovyet çekişmesinin Türkiye'nin konumunu daha önemli hale getirdiği ifade edildi ${ }^{77}$.

NATO’ya katılım, 18 Şubat 1952 de TBMM gündemine geldi. Türkiye'nin güvenliği konusunda kanlarıyla eşsiz hizmetlerde bulunan Kore kahramanlarına minnet ve şükran duyulması gerektiği vurgulandı. "Kore kahramanlarının katkılarına” işaret edildi ${ }^{78}$. Basında, Türkiye tarihinin dönüm noktalarından biri olarak görüldü̈ ${ }^{79}$. "Cevval politika"nın Türkiye’yi NATO'ya soktuğu, yoksa Batılıların ne karagözümüz ne de şirinliğimiz için bunu yapmayacağ ${ }_{1}$ belirtildi ${ }^{80}$. Türkiye'ye karșı bir vefa, bir dostluk borcu ödemek için değil, Türkiye'nin müşterek teşkilatta yer almasında "menfaat" gördüklerinden pakta almışlard ${ }^{81}$. Türkiye'nin Batı medeniyetine bağlı bir devlet olduğu onaylanmıştı ${ }^{82}$. Batı'nın Türkiye'ye bakış açısında ciddi değişiklikti ${ }^{83}$. Türkiye farklı din, dil ve kültür yapısı yüzünden Avrupa'dan dışlanmış, fakat Atatürk'ün "Avrupalılaşma” amacı doğrultusunda gerçekleştirdiği inkılaplarla bu farklılıkları ortadan kaldırmıştı ${ }^{84}$.

NATO'ya davet ve katılım sürecinde, savaş haber ve yorumları Çin'e odaklandı. Çin'in karışmasıyla savaş çıkmaza girmişti. Çin'e savaş açılması, Asyalı devletlerin karşı çıkmaları yüzünden mümkün değildi. Savaşın sonucu sadece bölgeyi etkilemeyecekti, ortak güvenlik davasının kaderi de bölgedeki kritik gelişmelere bağlıydı ${ }^{85}$.

Kaesong'ta başlayan ateşkes görüşmeleri dikkatle izlendi. Ateşkes kelimesini Sovyetler Birliği'nin taktik gereği kullandığı, ani bir saldırıyla

${ }^{75}$ Sedat Simavi, "Kore'nin Hikayesi-I,II,III,IV”, Hürriyet, 11-14 Temmuz 1951; Ali Naci Karacan,"Türkiye'nin Emniyeti Meselesi I-II", Milliyet, 12-13 Haziran 1951, "Artık İngiltere'ye Güvenemeyiz", 18 Haziran 1951.

${ }^{76}$ Sedat Simavi, "Türkiye Atlantik Paktı'nda", Hürriyet, 22 Eylül 1951.

${ }^{77}$ Ahmet Şükrü Esmer, “Atlantik Paktı'na Giriyoruz", Ulus, 23 Eylül 1951.

${ }^{78}$ TBMM Tutanak Dergisi, IX/2, C. 8, Ankara, 1952, s.314-322; Hürriyet, "Meclis Pakta İștirakimizi Tasvip Etti", 19 Şubat 1952; Ulus, "Kuzey Atlantik Paktına Resmen Girdik", 19 Şubat 1952; Milliyet, "Meclis, Kuzey Atlantik Paktına İltihakımızı İttifakla Tasvip Etti", 19 Şubat 1952

${ }^{79}$ Mümtaz Faik Fenik, “Yepyeni Bir Devre Giriyoruz”, Zafer, 18 Şubat 1952.

${ }^{80}$ Sedat Simavi, "Atlantik Cephesinde Türkiye", Hürriyet, 19 Şubat 1952.

${ }^{81}$ Nihat Erim, "Hadisenin Ehemmiyeti", Ulus, 20 Subat 1952.

${ }^{82}$ Nadir Nadi, "Kararın Manası", Cumhuriyet, 19 Şubat 1952.

${ }^{83}$ Ahmet Emin Yalman,"Kurucu Dış Siyaset", Vatan, 22 Aralık 1951.

${ }^{84}$ Hüseyin Cahit Yalçın, "Atlantik Misakında Türkiye”, Ulus, 23 Şubat 1952.

${ }^{85}$ Necmettin Sadak, "Kore Meselesi Askeri ve Siyasi Bakımdan Bir Çıkmaz İçindedir", Akșam, 4 Mart 1951. "Kore Harbi Şimdi Nasıl Bir Safhaya Girecek", 19 Nisan 1951. "Top Patlayınca Siyaset Susar Derlerdi”, 20 Nisan 1951. 
Kore'deki durumu lehine çevirmeyi amaçladı̆ ${ }_{1}{ }^{86}$ iddia edildi. Önemsiz konuların büyük sorunlarmış gibi algılanıp, ateşkes görüşmelerinin engellenmesi kötü niyete bağlandı ${ }^{87}$. Görüşmelerdeki tıkanıklık ve yavaşlığından ötürü K.Kore suçlandı. Çin sorumlu tutuldu. Esir sorununun çözümüyle birlikte ateşkes antlaşmasının imzalanacağı belirtildi ${ }^{88}$. Amerika, stratejik konumundan ötürü Kore'yi bırakmayacaktı ${ }^{89}$. Sovyetler Birliği nedeniyle görüşmelerin çıkmaza gireceği, Kore'deki düşmanın sadece K.Kore ve Çin olduğuna inanmanın saflık olacağı, Moskova yenilmedikçe bölgede ateşkes imzalanmayacağı da ifade edildi ${ }^{90} .1952$ ortalarından itibaren ateşkes görüşmelerinin ana eksenini "esirler sorunu" oluşturdu" Sorun, farklı ideolojideki esirlerin vatanlarına dönmek istememelerinden kaynaklanıyordu. Batı medeniyetinin, esirlerin zorla iade edilmesi gibi insanlık dışı bir işe girişmeyecekleri düşünülmekteydi. Bu, BM in savunduğu değerlerin anlamının kaybolacağının ifadesi olurdu.

Nisan 1953 'de hasta ve yaralı esirlerin değiştirileceği, ateşkes görüşmelerine tekrar başlanacağı haberleri barış umutlarını $\operatorname{artırd}^{92}$. Üç yıl süren ve üç milyon insanın yaşamına mal olan Kore Savaşı, 27 Temmuz 1953'te imzalanan Panmunjom Ateşkes Antlaşması ile sona erdi. Savaşın, Türkiye'nin safını belirlemede çok önemli olduğu, askeri sonucun sürpriz olmadığı, Türklerin bu savaşı kendi vatanlarına yapılmış bir saldırı gibi karşıladıkları ve onu savunur gibi dövüştükleri ifade edildi ${ }^{93}$. Türkiye'ye başta NATO olmak üzere uluslararası önemli kazançlar getirmişti. Emeği geçen askerlere teşekkür edildi ${ }^{94}$.

Sonuç olarak, Kore Savaşının tarafları olarak Sovyetler Birliği ve ABD görüldü. Sovyetlerin kışkırtıcı ve saldırgan olduğu, benzer saldırılara Türkiye'nin de hedef olabileceği varsayımında birleşildi.

Türkiye sorunu BM, dünya barışının geleceği, hürriyet ve barış dünyasına beslenen bağlılık olarak algılayıp taraf oldu. Dünya savaşına

${ }^{86}$ Nadir Nadi, "Sütten Ağzı Yanan”, Cumhuriyet, 3 Temmuz 1951. "Heyecanlı Bir Maç", 11 Temmuz 1951.

${ }^{87}$ Ahmet Sükrü Esmer, "Kaesong Görüșmeleri”, Ulus, 4 Ağustos 1951. "Kesilen Mütareke Görüşmeleri”,13 Eylül 1951.

${ }^{88}$ M. Feridun Bellisar, "Kore'de Mütareke Ümidi Var mı?" Hürriyet, 2 Haziran 1952; Ahmet Sükrü Esmer, "Mütareke Görüşmeleri", Ulus, 16 Ocak 1952.

${ }^{80}$ Diplomat, "Kore'de Mütareke Niçin Olmuyor?", Yeni Sabah, 27 Ocak 1952.

"Ömer Sami Coşar, "Sonu Gelmeyen Mütareke Görüşmeleri", Cumhuriyet, 4 Şubat 1952; Ahmet Sükrü Esmer, "Mütareke Görüşmeleri”, Ulus, 25 Nisan 1952.

${ }^{91}$ Ahmet Şükrü Esmer, "Son Söz", Ulus, 10 Mayıs 1952; Hüseyin Kandan, "Harp Esirleri Anlaşmazlığı”, Dünya, 10 Mayıs 1952.

${ }^{92}$ Hürriyet, "Mütareke Müzakereleri Kore'de Yeniden Başladı", 27 Nisan 1953; Ulus, “Kore'de Mütareke Görüşmeleri Başladı”, 27 Nisan 1953.

${ }^{93}$ Hürriyet, "Üç Yil Süren Kore Harbi'nin Bilançosu", 28 Temmuz 1953; Milliyet, "Kore Cephesinde Dün Resmen Ates Kesildi", 28 Temmuz 1953; Sedat Simavi, "Kore'de Mütareke", Hürriyet, 29 Temmuz 1953; Kore'de toplam 24822 Türk askeri görev yaptı. I. Kafile 5100, II. Kafile 5600, III. Kafile 7002 ve IV. Kafile 7100 askerden oluşmakta idi. Türkiye'nin kaybı; 721 sehit, 175 kayıp, 2147 yaralı olmak üzere toplam 3043 kişidir, Ateşkes Antlaşması ile 234 Türk esiri iade edildi. Erkilet, a.g.e., s.417,418-444.

${ }^{94}$ Mümtaz Faik Fenik, "Kore Harbi'nin Muhasebesi”, Zafer, 28 Temmuz 1953. 
dönüşme ihtimal ve tehlikesi dile getirtildi. Kore'ye asker gönderme kararı ile ilişkilendirilen konuların başında Türkiye'nin güvenliği bağlamında, Sovyet tehlikesi, ABD ile ilişkiler ve NATO yer aldı.

BM Ordusunda görev yapan Türkiye herhangi bir devlete savaş açmamıştı. Kore'de hem dünya güvenliği hem de Türk sınırını koruyarak, yarın olası bir saldırı karşısında yalnız kalmaktan kurtulacaktı. Karşı çıkılan Kore'ye asker gönderilmesinden çok, siyasilerin düşünceleri ve Meclis onayının alınmaması oldu. Eleştiriler, dış politikada ayrılık olduğu izlenimi doğurur, ülke çıkarlarını zedeler, birlik ve beraberlik havasını bulandırır gerekçeleriyle iyi karşılanmadı. Soğuk savaş ortamında Sovyetlere, dolayısıyla komünizme destek anlamı çıkarılır endişesi de farklı bakış açılarını frenledi.

Türk birlikleri Kore'de çeteleri yok etmek, yol ve köprü güvenliğini sağlamak ve BM Ordusunun kuşatılmasına engel olmakla görevlendirildi. Üstün sayıdaki düşmanla, yabancısı olduğu coğrafyada destan yaratırcasına savaştı. Başarısı, Türk-ABD ilişkilerini geliştirdi. ABD'nin Türkiye'yi müttefik olarak görmesi sonucunu doğurdu. Yardımının artacağı beklentileri çoğaldı.

Kore'ye asker gönderilmesi, sadece Türkiye'nin NATO'ya kabul edilmeme sürecinde eleştirilip sorgulandı. Tepki olarak tarafsızlık politikası gündeme getirildi. Batı "gaflet" içinde olmakla suçlandı. Kore savaşından ders alınması, askerlerimizin bir daha hayırsız dostlarımızın gönlünü hoş etmek için yeni maceralara sürüklenmemesi salık verildi. Ortak tehlike komünizme karşı Türkiye'nin olduğu kadar, ABD ve Batı'nın da Türkiye'ye ihtiyacı olduğu savunuldu.

Ateşkes görüşmeleri dikkatle izlendi. Özlenen barışın gecikmesi Sovyetler ile Çin'in kötü niyetine bağlandı. Esir sorununun çözümüyle mevzi çatışmasına dönüşen savaşın sona ereceğine inanıldı. Ateşkes sevinçle karşılandı.

Savaş, başta NATO olmak üzere önemli kazanımlar getirmişti. Karar eylem ve çekincelerde, $\mathrm{ABD}$ ve Batı dünyasının çekiciliğinden çok Sovyetlerin iticiliğinin etkili olduğu kendini gösterdi. 